\title{
Pemanfaatan Media Sosial sebagai Media Pemasaran Produk dan Potensi Indonesia dalam Upaya Mendukung ASEAN Community 2015. (Studi Social Media Marketing Pada Twitter Kemenparekraf RI dan Facebook Disparbud Provinsi Jawa Barat)
}

\author{
Ita Suryani \\ Dosen Akademi Komunikasi Bina Sarana Informatika, Jakarta
}

\begin{abstract}
Heading of ASEAN Community 2015, Indonesia should improve its role to increase Indonesian society to love local products, and to introduce Indonesian local products and potentials using internet and social media is the best solution.

The benefits and importance of social media is highly because social media has become a major pillar in the delivery of information. Social media can be used for socializing programs and policies, introducing the product and the potential of Indonesia, restoring and enhancing the image of tourism; and moreover, social media can be used as a means of learning communities.

The object of this research is social media account of Indonesian Ministry of Tourism and Creative Economy; and Department of Tourism and Culture, West Java. Using case study methods, these research concludes that a number of smart companies does not only use social networking media it as a marketing medium, but also as a supporter of business activity, simplify and strengthen the function of communication to the public.
\end{abstract}

Key words: Social media, Marketing, ASEAN Community

\begin{abstract}
Abstrak
Menghadapi Komunitas ASEAN 2015, Indonesia berperan untuk meningkatkan cinta produk dalam negeri bagi masyarakat domestik dan memperkenalkan produk dan potensi lokal Indonesia. Internet dengan memanfaatkan website, blog, dan media social dapat menjadi solusi untuk mempromosikan produk dan potensi lokal Indonesia ke mancanegara.

Media sosial telah menjadi pilar utama dalam penyampaian informasi. Media sosial dapat dipergunakan untuk sosialisasi program dan kebijakan, memperkenalkan produk dan potensi Indonesia, memulihkan dan meningkatkan citra pariwisata serta media sosial dapat dipergunakan sebagai sarana pembelajaran masyarakat.

Objek penelitian dalam tulisan ini adalah akun media sosial milik Kementerian Pariwisata dan Ekonomi Kreatif (Kemenparkeraf) RI dan Dinas Pariwisata dan Budaya Propinisi Jawa Barat. Menggunakan metode studi kasus, penelitian ini menyimpulkan bahwa sejumlah perusahaan yang cerdas, tidak hanya memanfaatkan media sosial sebagai media pemasaran, tetapi sudah menjadi pendukung aktivitas bisnis, mempermudah dan memperkuat fungsi komunikasi kepada publik.
\end{abstract}

Kata kunci : Media sosial, Pemasaran, Komunitas ASEAN 


\section{Latar Belakang}

Perhimpunan Bangsa-bangsa Asia Tenggara (Perbara) atau lebih populer dengan sebutan Association of Southeast Asian Nations (ASEAN) merupakan sebuah organisasi geo-politik dan ekonomi dari negara-negara di kawasan Asia Tenggara, yang didirikan di Bangkok, 8 Agustus 1967 melalui Deklarasi Bangkok oleh Indonesia, Malaysia, Filipina, Singapura, dan Thailand. Organisasi ini bertujuan untuk meningkatkan pertumbuhan ekonomi, kemajuan sosial, dan pengembangan kebudayaan negaranegara anggotanya, serta memajukan perdamaian di tingkat regionalnya.

Sejak ASEAN berdiri, Indonesia telah mengambil peran yang sangat penting. Peran pertama Indonesia ditunjukkan dengan ikut mendirikan ASEAN. Selanjutnya, Indonesia diberi kepercayaan sebagai penyelenggara KTT ASEAN I. KTT ini dilaksanakan di Bali pada tanggal 2324 Februari 1976. Salah satu kesepakatan yang dihasilkan KTT ASEAN I adalah pembentukan Sekretariat ASEAN di Jakarta.

Pada tahun 2015 nanti, ASEAN yang sekarang ini akan berintegrasi memasuki era baru yaitu era komunitas ASEAN 2015 yang lebih solid dan maju yang bercitacita mensejahterakan rakyat dan menjaga stabilitas keamanan di kawasan Asia Tenggara. Komunitas ASEAN 2015 sendiri terbagi dalam tiga pilar utama yaitu :

1. ASEAN Political-Security Community (Komunitas Politik dan Keamanan ASEAN)

Tujuan dibentuknya komunitas ini adalah untuk mendorong dan mempercepat terbentuknya kerjasama dalam bidang politik dan keamanan di kawasan Asia Tenggara dan menciptakan kedamaian dan stabilitas keamanan di kawasan negara ASEAN.

2. ASEAN Economic Community (Komunitas Ekonomi ASEAN)

Tujuan dibentuknya komunitas ini adalah tidak lain untuk meningkatkan stabilitas perekonomian di kawasan ASEAN. Membentuk kawasan ekonomi antar negara ASEAN yang kuat.

3. ASEAN Socio-Culture Community (Komunitas Sosial Budaya ASEAN)

Sedangkan tujuan dibentuknya komunitas ini adalah untuk memajukan dan mensejahterakan antar negara ASEAN dalam bidang sosial, kebudayaan, pendidikan, ilmu pengetahuan, kesehatan, dan masalah seputar sosial budaya.

Dengan terbentuknya ketiga pilar tersebut, diharapkan ASEAN Community 2015 akan benar-benar bisa terwujud. Dibentuknya ASEAN Community 2015 tidak lain adalah untuk mensejahterakan masyarakat di seluruh Asia Tenggara. Dari rakyat dan untuk rakyat ASEAN. Tentu saja cita-cita mulia komunitas ASEAN 2015 akan bisa terwujud manakala semua masyarakat ASEAN ikut mendukung lahirnya komunitas ini.

Dalam hal ASEAN Political-Security Community (Komunitas Politik dan Keamanan ASEAN) misalnya. Selain pemerintah dan pihak yang terkait yang telah turut aktif menjaga perdamaian dan keamanan, masyarakat juga harus aktif di dalamnya. Peran masyarakat cukup penting dalam hal ini bisa dilakukan dengan cara turut aktif menjaga keamanan dan kenyamanan di sekitar lingkungan masing-masing. Tidak membuat keributan, atau bertindak provokasi yang bisa menimbulkan 
Ita Suryani, Pemanfaatan Media Sosial sebagai Media Pemasaran Produk dan Potensi Indonesia dalam Upaya Mendukung ASEAN Community 2015. (Studi Social Media Marketing Pada Twitter Kemenparekraf RI dan Facebook Disparbud Provinsi Jawa Barat)

masalah keamanan. Melaporkan kepada pihak yang berwajib jika melihat ada hal yang mencurigakan di sekitar lingkungan yang berpotensi mengganggu keamanan.

Selanjutnya dalam hal ASEAN Economic Community (Komunitas Ekonomi ASEAN). Dalam bidang ini adanya pasar bebas ASEAN, menjadi hal yang mungkin dicemaskan oleh pelaku usaha yaitu kalah bersaing dengan produk luar negeri. Di era ini, meningkatkan mutu dan juga kualitas produk menjadi hal yang pokok dalam menghadapi ASEAN Community 2015. Dengan produk yang berkualitas maka produk bisa bersaing untuk diminati konsumen. Peran Indonesia dalam mendukung ASEAN Community dilakukan dengan kegiatan promosi atau memperkenalkan produkproduk lokal Indonesia. Dengan cinta produk buatan dalam negeri maka masyarakat ikut membantu kelangsungan para pelaku usaha lokal. Memperkenalkan produk melalui internet juga menjadi solusi dalam memasarkan produk lokal.Media yang digunakan untuk mempromosikan produk-produk dan potensi lokal Indonesia kemancanegara antara lain website, blog, dan sosial media seperti facebook dan twitter.

Internet sangat bermanfaat bagi berbagai aspek kehidupan, seperti pendidikan, perdagangan, ekonomi, dan pemerintahan. Dalam bidang pendidikan, belakangan ini banyak perusahaan atau penyedia barang dan jasa lebih memilih media internet untuk memasarkan produk yang mereka miliki. Mereka merasa sangat terbantu dengan kehadiran internet. Tidak ada lagi alasan keterbatasan pasar maupun biaya. Berbisnis melalui internet sangat efektif dan murah meriah. Siapapun, bahkan masyarakat yang belum memiliki pekerjaan juga bisa menggeluti bisnis via internet ini.

Kemunculan teknologi internet secara otomatis turut pula mempengaruhi perkembangan penggunaan media sosial di masyarakat. Media sosial adalah media online yang mendukung interaksi sosial. Media sosial menggunakan teknologi berbasis web yang mengubah komunikasi menjadi dialog interaktif. Beberapa contohnya antara lain, jejaring sosial, blog, wiki, youtube, dan lain-lain. Melalui media sosial, setiap orang bisa membuat, menyunting sekaligus mempublikasikan sendiri konten berita, promosi, artikel, foto, dan video. Selain lebih fleksibel dan luas cakupannya, lebih efektif dan efisien, cepat, interaktif, dan variatif.

Keberadaan media sosial kini terus merambah kehidupan manusia. Dalam perkembangannya media sosial bisa dimanfaatkan untuk beragam kepentingan, mulai menjalin pertemanan, kampanye program tertentu (pendidikan, sosial, agama, lingkungan, kesehatan, dan sebagainya), sampai promosi dan pemasaran produk atau jasa tertentu. Adanya kemajuan yang pesat dibidang teknologi informasi diimbangi dengan kemajuan teknologi transportasi dan manajemen logistik. Hal tersebut makin memudahkan terjadinya lalu lintas manusia sekaligus barang. Dua hal tersebut selayaknya menjadi peluang usaha yang harus dimanfaatkan. Dalam hal ini, bagaimana mendayagunakan media sosial seperti Facebook dan Twitter atau yang lainnya untuk memasarkan produk.

\section{Facebook}

Dominasi Facebook di bisnis jejaring sosial global semakin tak terbendung. tercatat dalam bulan September lalu, 
pengguna aktif bulanan Facebook kini sudah melewati angka 1,19 miliar akun. Dari angka tersebut, 874 juta pengguna di antaranya mengakses Facebook dari perangkat mobile. Pada bulan yang sama, secara rata-rata Facebook diakses secara aktif oleh 728 juta pengguna per hari, dengan 507 juta pengguna di antaranya merupakan pengakses Facebook dari ponsel dan tablet. Saat ini, pengakses Facebook dari perangkat mobile tercatat sebanyak 73,44 persen dari total pengguna. Tahun 2014 mendatang, jumlah pengakses Facebook melalui perangkat mobile diprediksi bisa mencapai 80 persen dari total pengguna. (http://tekno.kompas.com/read/2013/10 /31/1426203/Facebook.Tembus.1.19.Milia r.Pengguna.Aktif)

Facebook diperkirakan masih menjadi media sosial yang paling populer. Pada tahun 2012 diperkirakan jumlah pengguna mencapai 837,3 juta mengalami peningkatan $27,4 \%$ dari tahun sebelumnya. Di bawah ini adalah 10 negara pengguna Facebook terbesar di dunia, dan data menunjukkan bahwa Indonesia berada di posisi ke-4.

Tabel 1.Ranking 10 besar pengguna Facebook

\begin{tabular}{lll}
\hline \multicolumn{1}{c}{ Ranking } & \multicolumn{1}{c}{ Negara } & \multicolumn{1}{c}{ Jumlah Pengguna } \\
\hline 1 & Amerika Serikat & 156.820 .080 pengguna \\
2 & India & $45 \cdot 796.460$ pengguna \\
3 & Brazil & 44.622 .060 pengguna \\
4 & Indonesia & 42.684 .840 pengguna \\
5 & Meksiko & 33.088 .000 pengguna \\
6 & Turki & 30.991 .820 pengguna \\
7 & Inggris & 30.528 .320 pengguna \\
8 & Filipina & 27.331 .380 pengguna \\
9 & Perancis & 24.144 .640 pengguna \\
10 & Germany & 23.409 .180 pengguna \\
\hline
\end{tabular}

(Sumber: Nurudin 2012:73)

\section{Twitter}

Twitter merupakan sebuah situs web yang dimiliki dan dioperasikan oleh Twitter Inc. Situs ini menawarkan jaringan sosial berupa mikroblog sehingga memungkinkan penggunanya untuk mengirim dan membaca pesan yang disebut kicauan (tweets). Kicauan adalah teks tulisan hingga 140 karakter yang ditampilkan pada halaman profil pengguna. Kicauan bisa dilihat secara bebas, namun pengirim dapat membatasi pengiriman pesan ke daftar teman-teman mereka saja. Pengguna dapat melihat tweets penulis lain yang dikenal dengan sebutan follower (Rasuly dalam Nurudin, 2012:74).

Data pada tahun 2012, Indonesia menempati urutan ke-5 pengguna Twitter di dunia. Data tersebut menunjukkan bahwa jumlah pengguna Twitter di 
Ita Suryani, Pemanfaatan Media Sosial sebagai Media Pemasaran Produk dan Potensi Indonesia dalam Upaya Mendukung ASEAN Community 2015. (Studi Social Media Marketing Pada Twitter Kemenparekraf RI dan Facebook Disparbud Provinsi Jawa Barat)

Indonesia berada di atas Canada, Belanda, dan negara-negara Eropa lainnya (lihat Gambar 1).

Kementerian Pariwisata dan Ekonomi Kreatif RI atau yang dikenal dengan Kemenparekraf RI merupakan instansi pemerintah yang bergerak dibidang pariwisata dan ekonomi kreatif Indonesia. Wisatawan nusantara (wisnus) merupakan pasar yang sangat potensial bagi pengembangan pariwisata dan ekonomi kreatif. Dalam menginformasikan dan memperkenalkan produk dan potensi
Indonesia Kemenparekraf tidak hanya menggunakan website parekraf.go.id namun juga memanfaatkan sosial media twitter@ @kemenparekraf, karena sosial media memiliki peranan penting untuk melakukan penyebaran informasi mengenai program-program yang dirancang oleh Kemenparekraf bertujuan untuk meningkatkan rasa bangga dan cinta terhadap Indonesia serta mengkonsumsi produk ekonomi kreatif dalam negeri.

\section{Top 20 countries in terms of Twitter accounts}

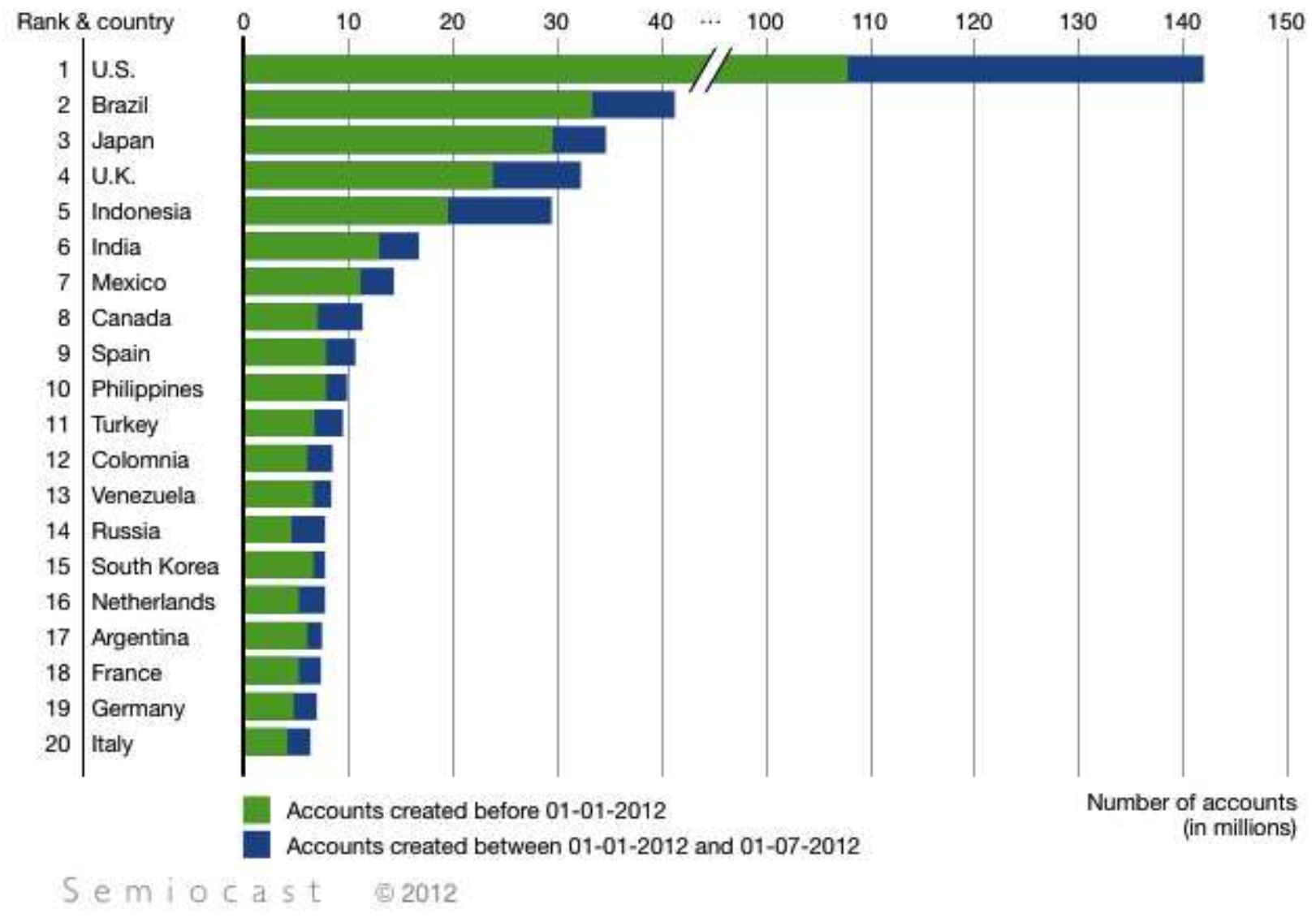

Gambar 1. Daftar 20 Negara Pengguna Twitter

(Sumber: http://www.salingsharing.com, 2012) 
Sedangkan Dinas Pariwisata dan Budaya Provinsi Jawa Barat (Disparbud) merupakan instansi pemerintah daerah yang memiliki pengaruh yang kuat pada mode dan seni sehingga Provinsi Jawa Barat dengan Ibu kota Bandung, dijuluki "Paris Van Jawa". Disparbud Provinsi Jawa Barat melakukan pembinaan, pelestarian dan pengembangan aset budaya yang mendukung upaya pengembangan pariwisata serta mempromosikan pariwisata Jawa Barat dengan memanfaatkan media website http:// disparbud.jabarprov.go.id dan media sosial facebook disparbud-provinsi-jawabarat.

Berdasarkan paparan diatas, media sosial saat ini sudah banyak dimanfaatkan masyarakat secara meluas, jejaring sosial atau dalam skala umum disebut dengan media sosial telah menjadi pilar utama dalam penyampaian informasi. Kecepatannya dalam menyalurkan berita menjadi pilihan masyarakat dunia di abad informasi ini. Hal tersebut juga dimanfaatkan oleh Kemenparekraf RI dan Disparbud Provinsi Jawa Barat dalam menginformasikan dan mempromosikan produk dan potensi yang ada di Indonesia maupun di Provinsi Jawa Barat seperti tempat wisata, produk-produk hasil karya kerajinan, kesenian, tradisi dan budaya serta jenis masakan atau kuliner.

\section{Tinjauan Pustaka}

\section{Media sosial}

Dari akar katanya yang pertama social merujuk pada strategi komunikasi atau cara orang berinteraksi. Kemudian media merupakan alat komunikasi seperti televisi, koran atau radio. Jadi sosial media adalah komunikasi 2 (dua) arah melalui tulisan, foto, video maupun audio yang disalurkan melalui internet (Riese, Pennisi \& Major, 2010:1).
Media Sosial yaitu sebuah kelompok aplikasi berbasis internet yang dibangun berdasarkan fondasi ideologis dan teknologi dari web 2.0, yang memungkinkan terjadinya penciptaan dan pertukaran konten yang diciptakan oleh penggunanya (Kaplan Andreas M. \& Haenlein Michael, 2010:59)

Media sosial merupakan bentuk nyata dari media baru (new media) berbasis kemajuan teknologi komunikasi yang didukung oleh teknologi informasi dan komunikasi (Information and Communication Technology). Media sosial dipahami sebagai bentuk baru komunikasi di internet yang ditopang oleh berbagai aplikasi software, yang memungkinkan terjadinya interaksi diantara para pengguna. Media sosial memiliki beberapa kelebihan, terutama pada kemampuannya dalam komunikasi dua arah yang interaktif, dan memudahkan penggunanya untuk mengakses berbagai macam informasi. Kondisi ini akan sangat mendukung komunikasi interaktif tanpa hambatan dan jarak. Didalamnya sangat dimungkinkan terjadi interaksi sosial baik antar individu, individu dengan kelompok, kelompok dengan kelompok, bahkan individu dan kelompok dengan massal. Beberapa situs media sosial yang populer pada saat ini adalah facebook, Twitter dan YouTube. Ketiganya masih akan menguasai dunia media sosial hingga dua tahun kedepan (Marketing, edisi 10/XIII/Okt 2013).

Pengguna facebook di Indonesia sejumlah 65 juta, dengan penetrasi facebook di Indonesia sebesar 93\% dari pengguna internet. Angka berikutnya 
Ita Suryani, Pemanfaatan Media Sosial sebagai Media Pemasaran Produk dan Potensi Indonesia dalam Upaya Mendukung ASEAN Community 2015. (Studi Social Media Marketing Pada Twitter Kemenparekraf RI dan Facebook Disparbud Provinsi Jawa Barat)

diikuti twitter dengan 30 juta pengguna, dan ini merupakan jumlah terbesar di Asia. Pengguna media sosial di Indonesia diprediksi akan mencapai 72 juta pengguna pada tahun 2014. Angka ini cukup fantasitis dan merupakan sebuah loncatan bagi proses komunikasi yang diantarai oleh media sosial. Aspek penting dari media sosial adalah proses interaksi yang berada pada jalur maya, yang menjadi bagian dari budaya massal. Kehadiran media sosial mampu menghilangkan batas ruang dan waktu, yang selama ini menjadi pembatas dalam berinteraksi bagi mereka yang berada pada tempat yang berjauhan. Dengan kondisi tersebut hadir istilah yang disebut sebagai global vilage. Istilah global village merupakan kondisi yang menganalogikan dunia sebagai sebuah desa yang besar dimana jarak sudah tidak lagi menjadi masalah dalam komunikasi. Dapat dikatakan bahwa dunia sudah tidak lagi bulat tetapi flat, karena dianggap semua individu bisa berada pada waktu yang sama untuk melakukan interaksi secara bersamaan (Hendroyono, 2012:206). Bagi perkembangan komunikasi, media sosial bahkan memungkinkan peningkatan nilai (value) dari para pelakunya.

Dalam teknologi komunikasi berbasis media sosial, perlu dikembangkan pendekatan komunikasi yang mensyaratkan beberapa hal (Hendroyono, 2012 :186) seperti tertuang berikut ini :

a. Transparant, dimana semua orang dapat mengakses dan semuanya terdokumentasi secara

digital,

b. Authentic, dimana didalamnya mengandung keunikan, karena ide yang dituangkan belum pernah ada sebelumnya, c. Genuine, tidak dibuat-buat,

d. Sincere, dimaknai sebagai kejujuran yang terkandung dari pesan yang disebarluaskan.

\section{Nilai dalam Pemanfaatan Media Sosial}

Bagi perkembangan komunikasi, media sosial memungkinkan peningkatan nilai (value) dari para pelakunya, dengan menggunakan prinsip membangun relasi antara perusahaan dengan follower atau fans. Nilai yang dimaksudkan disini adalah bagaimana setelah jalinan antara kedua belah pihak pelaku media sosial terwujud, terdapat dampak positif yang tidak hanya berimbas pada satu pihak saja, namun juga merambah pada cakupan yang lebih luas. Daya bidik media sosial terhadap pencitraan perusahaan maupun brand, bahkan mampu menurunkan biaya kampanye yang biasanya harus dilakukan secara konvensional oleh perusahaan.

Media sosial akan membentuk pola komunikasi yang menjanjikan adanya interaksi yang lebih intensif. Dalam Media sosial, publik follower atau fans bebas mengekspresikan apa saja yang ingin diungkapkan. Ruang media sosial sepenuhnya dapat dikendalikan oleh para follower atau fans, itulah sebabnya mengapa kedekatan (engagement) dapat terwujud, sebab kedekatan sudah tidak lagi berjarak dengan adanya interaksi timbal balik untuk memenuhi kebutuhan follower.

Dapat dikatakan bahwa ada proses seeding (menyemai) agar embrio pesan dari apa yang telah disebarluaskan perusahaan dalam media sosial, sehingga pada akhirnya dapat tumbuh dan berkembang. Pada tataran selanjutnya, akan dirasakan efek domino oleh seluruh 
pengakses media sosial. Pola komunikasi pada media sosial ini sesungguhnya merupakan proses transfer dari pola pengembangan kelompok, komunitas ataupun kerumunan yang ada pada dunia nyata yang dialihkan ke dunia maya. Cara yang diadopsi oleh media sosial tersebut, bahkan dapat menyentuh berbagai lini masyarakat yang berperan sebagai follower. Sehingga dalam konteks ini, semangat yang diangkat adalah pembentukan kolaborasi dari para pengguna media sosial.

\section{Komunikasi Pemasaran}

Menurut Prisgunanto (2006:8), Komunikasi pemasaran adalah "Semua dari marketing mix yang melibatkan komunikasi antar organisasi/perusahaan dan target audiens elemen-elemen pada segala bentuknya yang ditujukan untuk performance marketing".

Komunikasi pemasaran merupakan salah satu bauran promosi, di dalam marketing mix yang sangat penting dilaksanakan oleh perusahaan dalam pemasaran produk dan jasanya. Pada hakikatnya promosi adalah suatu bentuk komunikasi pemasaran, yaitu aktifitas pemasaran yang berusaha menyebarkan informasi, mempengaruhi atau membujuk, dan atau mengingatkan pasar sasaran atas perusahaan dan produknya agar bersedia menerima, membeli, dan loyal pada produk yang ditawarkan perusahaan (Tjiptono, 2006:35).

Menurut Tjiptono (2006:219) "Terciptanya konsistensi pesan, integritas kreatif, pemanfaatan media secara lebih optimal, efesiensi operasional, penghematan biaya, dampak komunikasi yang lebih besar dan terukur, dan akuntabilitas program Komunikasi pemasaran".
Menurut Stanton (1991:24), bauran promosi (promotional mix) yang paling banyak digunakan adalah periklanan (advertising) dan penjualan pribadi (personal selling). Bentuk promosi lain adalah promosi penjualan (sales promotion), publisitas, dan hubungan masyarakat (public relations). Tujuan utama dari promosi adalah menginformasikan (informing), mempengaruhi dan membujuk (persuading), serta mengingatkan pelanggan sasaran (reminding) tentang perusahaan dan bauran pemasarannya.

Komunikasi pemasaran memegang peranan yang sangat penting bagi perusahaan karena tanpa komunikasi, konsumen maupun masyarakat secara keseluruhan tidak akan mengetahui keberadaan produk di pasar. Komunikasi pemasaran juga secara berhati-hati dan penuh perhitungan dalam menyusun rencana komunikasi perusahaan. Penentuan siapa saja yang menjadi sasaran komunikasi akan sangat menentukan keberhasilan komunikasi, dengan penentuan sasaran yang tepat, proses komunikasi akan berjalan efektif dan efisien.

Menurut Kotler (2001:18), pemasaran sebagai suatu proses perencanaan dan menjalankan konsep, harga, promosi, serta distribusi sejumlah barang dan jasa, untuk menciptakan pertukaran yang mampu memuaskan tujuan individu dan organisasi. Menurut The American Marketing Association dalam Suyanto (2007:7), pemasaran sebagai proses perencanaan dan distribusi ide, barang dan pelaksanaan konsepsi, penetapan harga, promosi dan distribusi ide, barang dan jasa untuk menciptakan pertukaran yang memuaskan tujuan individu dan organisasi. 
Ita Suryani, Pemanfaatan Media Sosial sebagai Media Pemasaran Produk dan Potensi Indonesia dalam Upaya Mendukung ASEAN Community 2015. (Studi Social Media Marketing Pada Twitter Kemenparekraf RI dan Facebook Disparbud Provinsi Jawa Barat)

Menurut Rangkuti (2010:20), pemasaran adalah kegiatan manusia yang diarahkan untuk memuaskan kebutuhan dan keinginan melalui proses pertukaran. Tujuan pemasaran adalah untuk memahami keinginan dan kebutuhan konsumen agar produk atau jasa sesuai bagi konsumen sehingga produk atau jasa tersebut dapat terjual dengan sendirinya.

Menurut Rangkuti (2010:17), bahwa pemasaran bersandar pada konsep inti yaitu: (1) kebutuhan, keinginan dan permintaan, (2) produk/jasa, (3) nilai dan kepuasan, (4) pertukaran dan transaksi, (5) hubungan dan transaksi, dan (6) pasar.

\section{Bauran Pemasaran}

Lamb, Hair dan Mc Daniel (2006:21) menjelaskan bahwa bauran pemasaran adalah strategi produk, promosi, dan penentuan harga yang bersifat unik serta dirancang untuk menghasilkan pertukaran yang saling menguntungkan dengan pasar yang dituju.

Menurut Rangkuti (2010:22), bauran pemasaran adalah seperangkatyang digunakan perusahaan untuk mencapai tujuan pemasarannya dalam pasar sasarannya. Bauran pemasaran pada dasarnya terdiri atas empat bidang strategi pemasaran, yaitu :

1. Keputusan pemasaran yang akan mengubah ide dasar dari barang atau jasa keseluruhan.

2. Keputusan promosi yang akan mengkomunikasikan informasi yang berguna pada pasar tujuan.

3. Keputusan distribusi mengenai pengiriman produk kepada konsumen.

4. Keputusan harga yang menyatakan nilai pertukaran yang dapat diterima pada barang atau jasa.

\section{Teori Uses and Gratification}

Teori Uses and Gratifications model merupakan model kegunaan dan kepuasan model ini merupakan pergeseran fokus dari tujuan komunikator ke tujuan komunikan. Model ini menentukan fungsi komunikasi massa dalam melayani khalayak.

Menurut Effendy (2003:289), model Uses and Gratifications menunjukkan bahwa yang menjadi permasalahan utama adalah bagaimana media mengubah sikap dan perilaku khalayak tetapi bagaimana media memenuhi kebutuhan pribadi dan sosial khalayak. Jadi bobotnya ialah pada khalayak aktif, yang sengaja menggunakan media untuk mencapai tujuan. Pendekatan Uses and gratifications menyimpulkan bahwa situs Facebook dan Twitter dapat menjadikan penggunanya memiliki hak untuk memilih situs apa yang dapat memenuhi kebutuhannya akan berkomunikasi.

\section{Metode Penelitian}

Metodologi pada penelitian ini yaitu metode studi kasus. Menurut Rachmat Kriyantono (2006:66), metode studi kasus yaitu metode riset yang menggunakan berbagai sumber data yang bisa digunakan untuk meneliti, menguraikan dan menjelaskan secara komprehensif berbagai aspek individu, kelompok, suatu program, organisasi atau peristiwa secara sistematis.

Studi kasus adalah metode riset yang menggunakan berbagai sumber data (sebanyak mungkin data) yang bisa digunakan untuk meneliti, menguraikan, dan menjelaskan secara komprehensif berbagai aspek individu, kelompok, suatu program, organisasi atau peristiwa secara sistematis. Penelaahaan berbagai sumber data ini membutuhkan berbagai macam 
instrumen pengumpulan data. Karena itu, periset dapat menggunakan wawancara mendalam, observasi partisipan, dokumentasi-dokumentasi, kuesioner (hasil survei), rekaman, bukti-bukti fisik lainnya (Kriyantono, 2006: 65).

Sementara itu, Yin (2006:18) memberi batasan mengenai studi kasus sebagai riset yang menyelidiki fenomena di dalam konteks kehidupan nyata, bilamana batas-batas antara fenomena dan konteks tak tampak dengan jelas, dan di mana multisumber dimanfaatkan. Penggunaan metode studi kasus pada pembahasan jurnal ini adalah studi kasus dengan fokus pada pemanfaatan media sosial sebagai media pemasaran produk dan potensi Indonesia yang digunakan oleh Kemenparekraf RI dan Disparbud Provinsi Jawa Barat. Penggunaan studi kasus sebagai metode penelitian dipilih karena penelitian ini bertujuan memberikan uraian secara lengkap dan mendalam mengenai pemanfaatan media sosial sebagai media pemasaran dalam upaya mendukung ASEAN Community 2015 .

Data yang diperoleh akan dianalisis secara kualitatif yaitu analisis yang dilakukan dengan memahami dan merangkai data yang telah dikumpulkan dan disusun secara sistematis, kemudian ditarik kesimpulan.

Pawito (2008:102) mengemukakan bahwa dalam penelitian kualitatif, kesimpulan yang dihasilkan pada umumnya tidak dimaksudkan sebagai generalisasi, tetapi sebagai gambaran interpretatif tentang realitas atau gejala yang diteliti secara holistik dalam setting tertentu. Di sini, dikandung arti bahwa temuan apapun yang dihasilkan pada dasarnya bersifat terbatas pada kasus yang diamati. Oleh karena itu, prinsip berfikir induktif lebih menonjol dalam penarikan kesimpulan dalam penelitian komunikasi kualitatif.

Dengan demikian, metode kualitatif menurut Bogdan \& Taylor dalam Ruslan (2010:215), diharapkan mampu meghasilkan suatu uraian mendalam tentang ucapan, tulisan, dan tingkah laku yang dapat diamati dari suatu individu, kelompok, masyarakat, organisasi tertentu dalam suatu konteks setting tertentu yang dikaji dari sudut pandang yang utuh, komprehensif dan holistic.

Berdasarkan tataran atau cara menganalisis data, penelitian ini termasuk dalam jenis penelitian deskriptif. Sejalan dengan hal tersebut, Moleong (2002: 11) mengemukakan bahwa salah satu karakteristik dalam penelitian kualitatif adalah deskriptif. Dalam hal ini data yang dikumpulkan berupa kata-kata, gambar dan bukan angka-angka. Hal ini disebabkan oleh adanya penerapan metode kualitatif. Selain itu, semua yang dikumpulkan berkemungkinan menjadi kunci terhadap apa yang sudah diteliti. Dengan demikian, laporan penelitian akan berisi kutipan-kutipan data untuk memberi gambaran penyajian laporan tersebut.

Data yang diambil peneliti dalam penulisan ini didapat melalui studi kepustakaan atau sumber tertulis (library research). Secara umum definisi studi kepustakaan adalah usaha yang dilakukan oleh peneliti untuk menghimpun informasi yang relevan dengan topik atau masalah yang akan atau sedang diteliti. Informasi itu dapat diperoleh dari bukubuku ilmiah, laporan penelitian, karangan-karangan ilmiah, tesis dan disertasi, peraturan-peraturan, ketetapanketetapan, buku tahunan, ensiklopedia 
Ita Suryani, Pemanfaatan Media Sosial sebagai Media Pemasaran Produk dan Potensi Indonesia dalam Upaya Mendukung ASEAN Community 2015. (Studi Social Media Marketing Pada Twitter Kemenparekraf RI dan Facebook Disparbud Provinsi Jawa Barat)

dan sumber-sumber tertulis baik tercetak maupun elektronik lainnya.

Menurut Ruslan (2010:31) "Riset kepustakaan adalah riset yang dilakukan untuk mencari data atau informasi riset melalui membaca jurnal ilmiah, bukubuku, referensi dan bahan-bahan publikasi yang tersedia diperpustakaan”.

Data-data yang digunakan dalam pembahasan jurnal ini yaitu data secara studi pustaka diperoleh dari beberapa sumber buku dan sumber lainnya seperti internet yang relevan dengan pembahasan dan data dari laman facebook disparbudprovinsi-jawa-barat dan twitter @kemenparekraf.

\section{Pembahasan}

Kerjasama ASEAN memegang peran kunci dalam pelaksanaan kerjasama internasional Indonesia, karena merupakan pilar utama pelaksanaan politik luar negeri Indonesia. Selain terciptanya perdamaian dan stabilitas di kawasan, diharapkan dapat terus meningkatkan pertumbuhan ekonomi negara Indonesia.

Perkembangan positif yang signifikan dimana kerjasama ASEAN sekarang ini tengah menuju pada tahapan baru yang lebih integratif dan berwawasan ke depan melalui pembentukan ASEAN Community pada tahun 2015, yaitu sebuah komunitas yang berpandangan maju, hidup dalam lingkungan yang damai, stabil dan makmur, dipersatukan oleh hubungan kemitraan yang dinamis dan masyarakat yang saling peduli.

Banyak tantangan yang harus dihadapi ASEAN khususnya Indonesia seiring dengan perkembangan pesat di bidang politik, keamanan, ekonomi, sosial, budaya, teknologi dan bidang lainnya. Indonesia menyadari pentingnya upaya untuk berperan aktif dan melibatkan masyarakat guna mendukung terlaksanannya ASEAN Community 2015 yang dapat memberikan manfaat langsung bagi masyarakat. Salah satu yang dilakukan oleh pemerintah Indonesia dalam bidang ekonomi, sosial dan budaya yaitu dilakukan dengan cara cinta produk dalam negeri, memperkenalkan produk dan potensi lokal Indonesia melalui internet juga menjadi solusi dalam memasarkan produk lokal. Dapat menggunakan website, blog, dan sosial media untuk mempromosikan produkproduk dan potensi lokal Indonesia ke mancanegara, seperti yang dilakukan oleh Kementerian Pariwisata dan Ekonomi Kreatif (Kemenparekraf RI) serta Dinas Pariwisata dan Budaya Provinsi Jawa Barat (Disparbud) yang memanfaatkan media sosial facebook dan twitter dalam memperkenalkan atau memasarkan produk dan potensi budayanya.

Sesuai dengan fungsi dan peranannya sebagai media pemasaran, maka media sosial juga dapat digunakan untuk mempromosikan kepariwisataannya ke seluruh negara di dunia. Media sosial tidak hanya dijadikan basis pertahanan suatu perusahaan dalam menjual produk atau jasanya melalui iklan. Akan tetapi suatu negara pun dapat menggunakan media sosial untuk menarik minat wisatawan mancanegara maupun domestik untuk berkunjung ke suatu tempat. Hal ini yang pernah dilakukan oleh suatu komunitas di Indonesia yang mengajak seluruh masyarakat Indonesia untuk memajukan objek wisata yang dimiliki agar dikenal di seluruh dunia.

Akun twitter@ @kemenparekraf diluncurkan tahun 2010 aktif sampai dengan saat ini dengan followers sebanyak 561. Penggunaan layout yang minimalis, warna-warna cerah, serta 
penambahan fitur galeri video membuat situs ini semakin komprehensif. Situs ini menyediakan informasi dan berita berupa destinasi wisata, atraksi, serta berbagai acara pariwisata di Indonesia. Akun twitter@kemenparekraf juga digunakan untuk mempromosikan pariwisata tanah air dan mensosialisasikan programprogram yang akan dan telah dilaksanakan oleh Kemenparekraf RI.
Hadirnya akun twitter @kemenparekraf diharapkan masyarakatsemakin mudah mendapatkan informasi produk dan potensi pariwisata Indonesia. Sebab internet sudah menjadi sumber utama informasi. Harapan lainnya tentu semakin banyak lagi jumlah wisatawan domestik dan mancanegara yang berkunjung ke Indonesia.

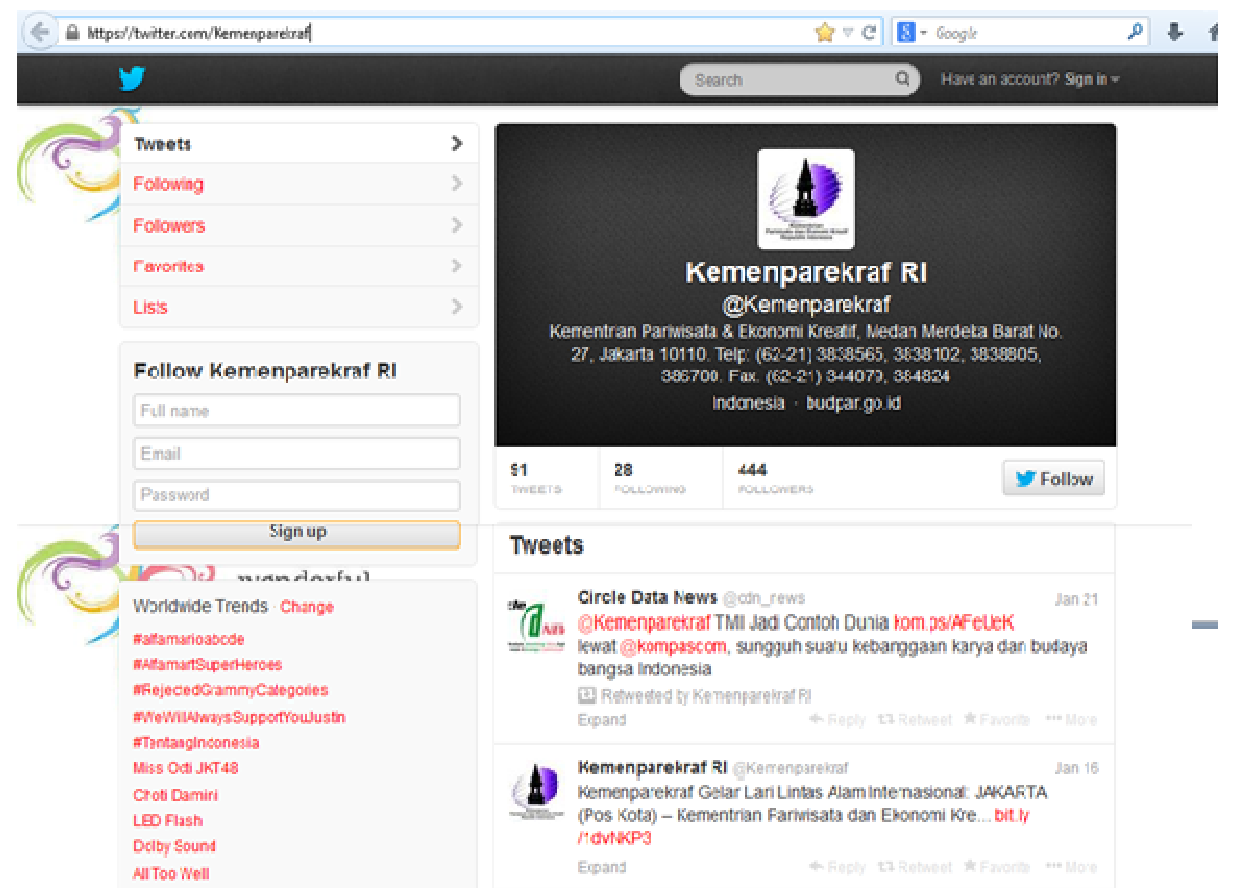

Gambar 2. Twitter Kemenparekraf RI

(Sumber:https://twitter.com/kemenparekraf)

Akun facebook Disparbud Provinsi Jawa

Barat diluncurkan pada tahun 2011 dengan tujuan sebagai media penyampai informasi khususnya mengenai peningkatkan kunjungan wisatawan, lama tinggal wisatawan, belanja wisatawan, pertumbuhan investasi dibidang kepariwisataan dan kebudayaan. Aktivitas komunikasi pada akun ini masih berjalan efektif sampai dengan saat ini dilihat dari banyaknya masyarakat yang menyukai halaman facebook disparbud provisnsi jawa barat yaitu sebesar 1.953 fans. Pesan yang disampaikan pada akun facebook tersebut yaitu mengenai event/kegiatan pariwisata, objek wisata, ikon pariwisata di Jawa Barat, kesenian, situs bersejarah, dan informasi mengenai perkembangan pariwisata dan budaya yang ada di Provinsi Jawa Barat. 
Ita Suryani, Pemanfaatan Media Sosial sebagai Media Pemasaran Produk dan Potensi Indonesia dalam Upaya Mendukung ASEAN Community 2015. (Studi Social Media Marketing Pada Twitter Kemenparekraf RI dan Facebook Disparbud Provinsi Jawa Barat)

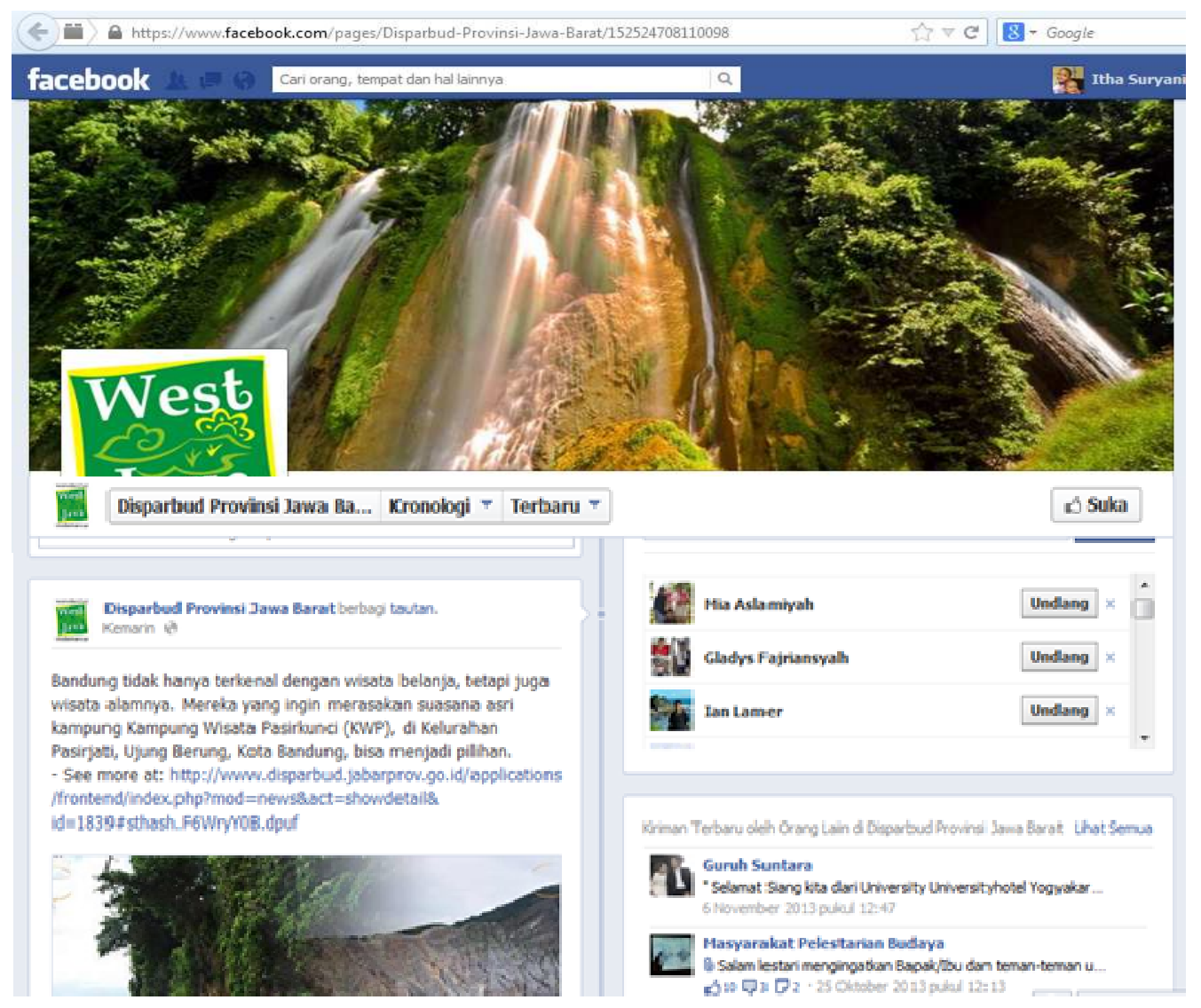

\section{Gambar 3. Facebook Disparbud Provinsi Jawa Barat}

(Sumber : https://www.facebook.com/pages/Disparbud-Provinsi-Jawa Barat/152524708110098)

Dikaitkan dengan teori uses and gratifications yaitu bagaimana media mengubah sikap dan prilaku khalayak tetapi bagaimana media memenuhi kebutuhan pribadi dan sosial khalayak. Dalam sosial media yang digunakan oleh Kemenparekraf RI dan Disparbud Provinsi Jawa Barat informasi yang disampaikan sampai saat ini dapat dikatakan efektif sebagai sumber informasi bagi masyarakat yang ingin mengetahui produk dan potensi baik itu di Provinsi Jawa Barat maupun potensi tanah air. Diharapkan dengan adanya sosial media twitter @kemenparekraf dan facebook disparbud-provinsi-jawa-barat dapat mendukung Indonesia dalam ASEAN Community 2015 mendatang.

\section{Kesimpulan}

Dengan berkembangnya teknologi komunikasi tentu saja memiliki dampak, baik dalam segi positif maupun negatif. Terlebih lagi setiap industri memerlukan metode untuk memasarkan produk atau jasanya dengan sedemikian rupa, mulai dari cara yang tradisional maupun modern yang berbasis internet. Hal ini ditunjukkan dengan meningkatnya kebutuhan masyarakat akan informasi. Informasi yang sesuai dengan latar belakang budaya masyarakat akan diterima, sedangkan yang tidak sesuai akan cenderung diabaikan atau bahkan ditolak. Karena itu, pengguna media sosial dituntut agar dapat memahami dimana mereka akan menyebarkan informasi atau 
mengetahui khayalak sasarannya sekaligus latar budaya yang dimiliki.

Berdasarkan paparan diatas dapat disimpulkan bahwamedia jejaring sosial saat ini bukan lagi sekadar laman pertemanan, tetapi sudah menjadi gelombang baru ekonomi. Sejumlah perusahaan yang cerdas, tidak hanya memanfaatkannya sebagai media pemasaran, tetapi sudah menjadi pendukung aktifitas bisnis. Karena itu, saat ini tidak sedikit industri yang lebih dinamis dalam menciptakan produk. Bingkai bisnis yang menciptakan produk sesuai keinginan industri sudah bergeser. Perusahaan atau instansi pemerintah saat ini mulai mengolaborasi berbagai informasi mengenai keinginan publik dari berbagai sumber, khususnya lewat dunia maya.

Seperti yang dilakukan oleh Kemenparekraf RI dan Dispardub Provinsi Jawa Barat memanfaatkan media sosial facebook dan twitter sebagai media dalam memasarkan dan memperkenalkan produk-produk serta potensi lokal Indonesia kepada publik dan mancanegara. Seperti tempat wisata, produk-produk, kesenian dan budaya serta jenis masakan atau kuliner yang ada di sekitar kita dan sebagainya.
Dengan menulis dan mereview tempat-tempat wisata yang ada disekitar kita, maka kita sebenarnya telah aktif dalam memperkenalkan wisata ke mancanegara. Dengan begitu akan ada minat wisatawan baik lokal maupun luar negeri untuk berkunjung. Hal lain juga tak ada bedanya, kita bisa menulis dan mereview tentang produk-produk, kesenian, kuliner, dan sebagainya yang ada di sekitar kita di sebuah media sosial. Karena dengan menggunakan sarana sosial media seperti facebook, twitter, dan sebagainya dapat digunakan untuk berinteraksi serta menjalin komunikasi dengan publik yang lebih luas.

Dengan adanya pemanfaatan media sosial dalam memasarkan dan memperkenalkan produk serta potensi lokal yang ada di sekitar, maka diharapkan negara Indonesia dapat mendukung ASEAN Community 2015 oleh rakyat dan untuk rakyat.

Dalam tulisan ini penulis lebih memfokuskan pada media sosial yang digunakan oleh Kemenparekraf RI dan Disparbud Provinsi Jawa Barat. Meski demikian penulisan ini dapat dilanjutkan dengan kajian mengarah kepada konvergensi media baru ataupun dengan objek lain. 
Ita Suryani, Pemanfaatan Media Sosial sebagai Media Pemasaran Produk dan Potensi Indonesia dalam Upaya Mendukung ASEAN Community 2015. (Studi Social Media Marketing Pada Twitter Kemenparekraf RI dan Facebook Disparbud Provinsi Jawa Barat)

\section{Daftar Pustaka}

Effendy, Onong Uchjana. 2003. Ilmu Teori dan Filsafat Komunikasi. PT. Citra Aditya Karya. Bandung.

Hendroyono,Handoko. 2012. Semua Orang Adalah Brand Gardener. Literati. Jakarta.

Kaplan, Andreas M, Michael Haenlein. 2010. "Users of the world, opportunities of Social Media". Bussines Horizons.

Kotler, Phillip. 2001. Marketing Management: Analysis, Planning, Implementation and Control, Millenium Edition. Prestice Hall Inc. New Jersey.

Kriyantono, Rachmat. 2006. Teknik Praktis Riset Komunikasi. Kencana Prenada Media Group. Jakarta.

Lamb, Hair and McDaniel. 2006. Marketing $6^{\text {th }}$ Edition. Thomas SouthWestern.

Marketing, Majalah. Ed 10/XIII/Oktober 2013. Seberapa Baik Percakapan Atas Merek Anda, Gramedia. Jakarta.

Moleong,Lexy, J. 2002. Metode Penelitian Kualitatif. PT. Remaja Rosda Karya. Bandung.

Nurudin. 2012. Media Sosial Baru dan Munculnya Revolusi Proses Komunikasi. Buku Litera. Yogyakarta

Pawito. 2008. Penelitian Komunikasi Kualitatif. LKIS Pelangi Aksara. Yogyakarta.

Prisgunanto, Ilham.2006. Komunikasi Pemasaran: strategi dan taktik . GhaliaIndonesia. Bogor
Rangkuti, Freddy. 2010. Strategi Promosi Yang Kreatif dan Analisis Integrated Marketing Communication. PT gramedia pustaka utama. 2010. Jakarta.

Ruslan, Rosady. 2010. Metodologi Penelitian Public Relations dan Komunikasi cetakan ke-5. Rajawali Pers. Jakarta.

Riese, M., Pennisi, L., \& Major, A., (2010). Using Social Media To Market Your Business. Nebraska Lincoln.

Stanton, William, J. 1991. Fundamental Of Marketing. Seventh Edition. Mc. Graw Hill, Inc.

Suyanto, M, 2007. Marketing Strategic Top Brand Indonesia. Andi Offset. Yogyakarta.

Tjiptono, Fandy. .2006. Pemasaran Jasa. Cetakan ke-2. Bayu Media. Malang.

Yin, K, Robert. 2006. Studi Kasus Desain \& Metode. PT. RajaGrafindo Persada. Jakarta

\section{Sumber lain :}

http://tekno.kompas.com

http://www.salingsharing.com

https://twitter.com/kemenparekraf

https://www.facebook.com/pages/Dispar

bud-Provinsi-Jawa

Barat/152524708110098 
Jurnal komunikasi, Volume 8, Nomor 2, April 2014 